\title{
The Implementation of Salam-Contract For Agriculture Financing Through Islamic-Corporate Social Responsibility (Case Study of Paddy Farmers in Tuban Regency Indonesia)
}

\author{
Ahmad Hudaifah $^{1}$, Bambang Tutuko ${ }^{2}$, Tjiptohadi Sawarjuwono ${ }^{3}$
}

\begin{abstract}
This research is aimed at discovering a stable financial scheming formula or model that would be compatible with the natural characteristics of a paddy farming cycle in Tuban. The qualitative research employs the use of an active participatory community through the means of a focus group discussion, an in-depth interview and face to face interviews with respective stakeholders and key informants. The Salam contract, which is highly beneficial is a prospective financial scheme that terminates the long business chain found in most businesses in Indonesia. The Corporate Social Responsibility which is managed through the Syariah approach (I-CSR) from a company, can become the solution to bridge the gap found in the implementation of funds for a Salam contract. The Salam contract applicability is dependent on the Islamic farmer cooperatives (BMT), a unit of joint venture organization serving as the key players in the execution of the function of a paddy warehouse-trading agent and direct financing to farmers. Strong support also comes from the zakat, infäq, and shodaqoh institution (LAZ) whose role is educating and encouraging the paddy farmers' skills and competency, especially to enable them access end-user markets using the aid of information technology.
\end{abstract}

Keywords: Salam, I-CSR, Cooperative, Farmers

\begin{abstract}
Abstrak. Penelitian ini betujuan untu menemukan formula skema pembiayaan pertanian yang stabil sesuai dengan karakteristik alamiah pertanian padi di Kabupaten Tuban. Metode penelitian kualitatif dipergunakan dalam menyelesaikan penelitian ini dengan partisipasi aktif komunitas melalui media diskusi kelompok, wawancara mendalam tatap muka dan observasi kepada informan kunci dan pihak yang terlibat secara langsung dalam tataniaga pertanian padi di Kabupaten Tuban. Kontrak salam adalah skema pembiayaan yang sangat menguntungkan bagi petani dan pada aplikasinya mampu mengambil peran pembiayaan distributor dalam tata niaga pertanian padi. Islamic Corporate Social Responsibility (I-CSR) yang dikelola berdasarkan prinsip ekonomi Syariah dari perusahan yang beroperasi di wilayah Tuban bisa menjadi solusi dana yang dikembangkan untuk pembiayaan pertanian yang dihindari oleh perbankan karena siklus bisnis yang berbeda. Keberlangsungan
\end{abstract}

1,2,3 Department of Islamic Economics, Universitas Internasional Semen Indonesia

E-Mail: ${ }^{1}$ ahmadhudaifah@gmail.com, ${ }^{2}$ bambang.tutuko@uisi.ac.id, ${ }^{3}$ tjiptohadi@uisi.ac.id 
kontrak salam pertanian untuk komoditas padi akan bergantung pada koperasi petani yang terdiri dari koperasi simpan pinjam Syariah (BMT), gudang padi, penggilingan padi dan unit perdagangan yang kesemuanya disebut sebagai $K U B$ (Kelompok Usaha Bersama). Dukungan yang kuat juga berasal dari Lembaga zakat, infäq dan shodaqoh, yang memiliki peran untuk melakukan pelatihan keablian petani dan membantu memenubi kebutuhan dasar petani yang menjadi anggota dalam $K U B$.

Kata kunci: Salam, I-CSR, Koperasi, Petani

\section{Introduction}

From the perspective of the Indonesian Islamic banking, the implementation of the Salam contract financing as stipulated in Fatwa DSN MUI No. 5/2000 for the agricultural and plantation sector is a very much challenging and uneasy task. Based on the Indonesia Financial Service Authority (OJK/Otoritas Jasa Keuangan) report, the Salam contract for agriculture, one of the most minority products provided by the Islamic banks of Indonesia, constitutes less than 1 percent of the Islamic banking financing. The main problem of executing and structuring a Salam contract for Islamic banking in Indonesia is the distinction found in the business cycles of the banking business and farming activity. Banks as financial merchants must have their work ethics conform with the nature of financial services and be ready for cash flow availability regularly, which could be daily or monthly. As part of the consequences, employing the Salam contract requires a monthly payment of a fixed or negotiable amount of money. From another angle, when the Salam contract is executed through a single process; involving the Islamic bank and the farmers only, the Islamic bank would have to deal with the challenges involved in the storing and trading process of agricultural products.

The existence of a flexible third-party fund in terms of its usage compatibility and profit-sharing responsibility is also a research issue which must be dealt with in the analysis. Another reason is that the bank is usually unable to structure and offer the salam contract because of the liability attachment to its customers. They should be ready to entertain any cash withdrawal and transfer from customers at any time of the request. In addition, the bank must enforce profit-sharing regularly as a banking common financial behaviour. In reality, farming nature cycles such as paddy for instance, in reality, takes more than a month to give the farmers opportunity to monetize their harvests after selling to middlemen or the markets. The nature of the agricultural business proses runs for a longer period, usually, four months involving cultivation, fertilization, harvest and vending. 
Based on the statistical data from the application of agricultural financing by the Islamic bank, murabahah or Mudarabah contract is more reliable from the banks perspective. Usage of these two contracts also demands collateral in the form of land ownership certificate or motor vehicle ownership certificate as well as regular payment. Those requirements are authorized by the DSN MUI fatwa Number 7/2000. Unfortunately, it is incompatible and unsuited for the nature of the agricultural business process, particularly for small and micro-scale farmers. In the implementation, based on the observations from several regions and discussions with Islamic bank practitioners, farmers must collateralize their land and valuable asset such as jewellery or vehicles when they are proposing a financing schemes to Islamic commercial banks, Islamic rural bank or Islamic cooperatives for the purpose of having a working capital in their planting phases. However, farmers are expected to pay back a financing scheme on a monthly basis after 3 to 4 months as regards to receiving income from selling their harvested products. In cases of small and micro-scale farmers, taking a financing contract or scheme from Islamic banking is difficult to achieve due to the lack of valuable collateral.

Tuban Regency is selected with a reasonable background as one administrative area located in north coastal line of Java Island with agglomeration of less developed farming and growing farming industry. According to statistical data issued by Tuban local government in 2017, the contribution to the GDP for Tuban economy is dominated by the manufacturing industry and the agricultural sector accounting for 28.32 percent and 21.33 percent. One of the agricultural economic sector which seems to be more common in Tuban Regency is rice or paddy farming. There is not only land suitability for paddy farm, but it also goes in line with the national food security program that enables Tuban to become one of national paddy producers. Tuban rice production reaches about more than 588 thousand tons with the land farming productivity abound 62 quintals per hectare. Local potency with expansive government program in paddy farming is supposed to be a gateway for farmer's economic welfare. Thus, it is expected that with a good financing mechanism and an effective agricultural modified program, farmers can ignore taking financing scheme from money lender, loan shark and middlemen buying the harvest with lower price. Unfortunately, many paddy farmers, due to the shortage of cash flow, can barely finance their living cost. Lack of personal finance management has forced them to take any loan available to them and also sell their harvest to middle man.

In line with the growth of the manufacturing industry, Tuban regency as a national pillar of paddy producers with negative social impacts such as carbon pollution as well as deteriorating urban planning tends to be compensated with the 
corporate social responsibility fund. The CSR fund from companies runs under a mandatory of Act Number 40/2007, which stipulates an obligation from any liable business entities to allocate their CSR fund as a means of environmental and social compensation. The majority of CSR funds goes to charity program and local infrastructural development and does not require a longer term of productive allocation. The reason why CSR fund is directly spent on society is attributable to two major reasons: the surrounding pressures and the company objectives. Such CSR fund allocation programs are designed to cater to several programs like free medical treatment for the poor and building roads or monuments. One feature program that seems to have a wider reach is the training of vulnerable residents with skills and capacity, such as pastry and cooking training and online marketing through social media for small and micro-enterprises.

CSR fund is a source of free, flexible and cheap internal financing designed specifically for agriculture salam contracts. A portion of CSR fund allocation, for example, 10 up to 20 percent, is needed to support these financing schemes. The majority of CSR fund as a strategic social communication for the corporation should be utilized for infrastructures and direct disbursement. The CSR fund allocated for agricultural financing has to be managed by professional Islamic financial intermediaries such as Islamic commercial banks, Islamic rural banks, and Islamic cooperatives (BMTs). Optimization of productivity for the CSR fund can be attained by employing an Islamic-CSR Model that involves forward and backward linkage under Islamic permissible contracts and screening process. As an obligatory condition, CSR funds should be managed productively and prudently. The availability of flexible free fund can help to overcome the tough challenge of salam contracts implementation for small and micro agriculture. The development of a productive CSR fund may bring about benefits and support to enable the creation of welfare for farmers in Tuban areas.

\section{Literature Review}

Financing with salam contract is an appropriate financing model for agriculture. Farmers receive money (fund) as initial payment or down payment for cultivating clearly stated quantity and quality of farm products between the contracting parties (Al Zaabi, 2011). Salam contract is considered the most suitable Islamic banking products for agricultural sectors, compared to other products (Ehsan dan Shahzad, 2015). Qustonoah (2016) has done a critical analysis of the implementation of salam financing contract for the agriculture sector in Indonesia. The incredible development of Islamic banking industry does not encourage the 
various products for society. Islamic banking has been placed in a safe position by offering low-risk products dominated by murabahah, Mudārabah, and fee-based income with regards to securing and channelling funds. The research has concluded that the Islamic bank industry should start developing a salam financing contract as financial responsibility to realize the variety of financing contracts available for society. The existence of salam contract scheme is expected to discontinue any agriculture business chain that many intermediaries have benefited from so that farmers can have direct access to the end-users in the market.

From the company's perspective, CSR is defined to have an inherent benefit to boost company performance (organizational performance). Thorne and Farrell (2008) declared that the importance of CSR role is enhancing the relationship between stakeholders and company, empowering performance and creating benefits in all aspects. They also explain that restraint on CSR at leash brings about four advantages for the company which includes; customer and employee trust, customer satisfaction, employee commitment, and investor loyalty, whereas such four factors affect the company's performance. Charles J. Fombrun (1997) constructed the implementation stage of CSR theory which was proposed by Carrol A.B. (1991) to engage all stakeholders to support the company for better performance. Social responsibility has to be a strategic planning scheme for companies. To achieve strategic objective, social responsibilities should involve all stakeholders starting from the employees to investors, customers, business partners, communities, government and environment.

The development of the corporate social responsibility concept in Islam has a comprehensive principle meaning. To manage a business, a company is essential to maintain environmental quality, pay employees very well, observe regulations and be responsible for the vulnerable surrounding society particularly surrounded by the poor (Taman, 2011). The fundamental concept of CSR, though been developed by the western social scientist and modern company, is in line with the Islamic economic principles. Company or business individual who holds Islamic principles to high esteem must engage in programs and activities influencing the vulnerable society. In the Quran, the basic principle of CSR is postulated in several verses such as Quran surah al-Baqarah: 177, al-Taubah 71 [QS.9: 71], an-Nahl:90, and al-Ma'un:1-7. The Islamic-CSR concept is considered to be holistic and integrated because of the engagement of other Islamic economic entities such as the zakat institutions and Islamic cooperatives along with the farmers' groups. The primary task of the Islamic social system is to determine the relationship between humankind and God from the beginning of inter-human relation (Akhtar, 2007). 
To mention some of the many studies, the application of the concept of CSR in Islam began with Akhtar (2007) who tried to bridge the gap of CSR development theory in the western perspective and Islam. This research is written in a doctoral dissertation in striving to build a conceptual framework for CSR in Islam. The CSR concept is not alien and would not be new in Islam when implemented in the right direction. Islam obliges individuals as well as companies to not only to seek profits but also care about the environment and the society before gaining any financial profit. Companies and organizations applying the basic Islamic principles are certainly in line with the primary principles of CSR depending on the level of their economic operation. In Islam, a company should not expect to gain financial profit when practicing the principles of CSR because when they are preserving the nature by reducing or recycling waste in the right manner is also part of social responsibility. The distinctive principles between the western and Islamic CSR perspective lie in reputation and image aspect rather than the priority of religious objectives. Islamic CSR concept strives to achieve more religious dimension as well as company's image.

The application of salam contract financing (Bay'salam) is established and offered by several Islamic banks in Pakistan. A study conducted by Kaleem dan Wajid (2009) shows that the salam contract was very popular for use in the agricultural financing products in Pakistan. Employing primary data using the questionnaire survey in Punjab state, the study shows that the majority of farmers need financing at the beginning of their cultivating period to settle the cost of farming such as buying seeds and fertilizer. The application of salam financing contract will help farmers to avoid money lenders and intermediaries with excessive lending rate to farmers.

Empirical research conducted through a direct questionnaire survey by Adi Fajar (2013) about the salam contract acceptability for farmers financing in Bogor regency concludes that majority of farmers can comprehend the salam contract as a mode of financing. This study uses behavioural analytical approach, subjective norm, and comparison between bay al-salam acceptability and the moneylender with farmers as the object of consideration. The finding explains that whenever salam financing scheme is offered, farmers will consider the contract. Their open views begin with the farmer's negative perspective on the money lending schemes in financing agricultural production as the bondage system that excessively exhausts the farmer's harvest selling. The research has also concluded that the application of the salam contract application will improve farmers' income because of the free and fair agricultural pricing system. Farmers can patiently wait and see the trade from 
their agriculture harvest in order to reach a higher price and also proceed with more added-value.

A study by Rozik et al. (2014) with a sample of farmers from Jember regency shows that salam financing contract was not proposed by Islamic cooperatives and Islamic banks. The research finding has emphasized information and data that shows salam financing contract as the most voided product offered by the Islamic finance and banking industry. This problem is rooted in the difficulty of the Islamic banking and finance industry to structure and secure salam contract into a reliable product. Such challenge for the industry is due to the intermediary function of the banking and difficulty in extending the bank service into trading unless the bank forms a subsidiary or special unit. One possible solution to implement salam contract is to develop a parallel contract engaging other trader parties, but unfortunately, none of the Islamic banks in Jember is interested in structuring these products.

The Central Bank of Indonesia (2015) released a recommendation for an agriculture financing scheme that requires all process in the agricultural financing to follow the nature of the agribusiness chain rather than the commercial banking sector. Every agricultural business research should refer to the three key factors that surround the value chain of agribusiness. The first being the involvement of value chain players, namely producers, group of producers, rural logistics company, suppliers, rice mill unit, traders (exporters, retailers, manufacturers). Secondly, modern markets are particularly seen as a top priority in the agriculture value chain of financing. Thirdly, the production system facility spread around the order penetration area or customer order to decouple the points. The agriculture financing scheme has to look at the whole aspect of the business chain.

\section{Research Method}

The research methodology involved in undertaking and developing the findings of the research paper combines three steps of approaches; Literature study, (2) FGD (Focus Group Discussion), and (3) Interviews. The first step is to build a conceptual and thinking framework which would interact with the salam contract financing and the Islamic-CSR model. To achieve these goals, a desk study is conducted by examining the literature collection, then the feasibility of the conceptual implementation is tested using the FGD and interview steps with key informant and stakeholders on this research. To sharpen the analysis and come up with a holistic solution, the case study needs to be selected (Yin, 2009). 
Graph 1: Desk Study Process Diagram

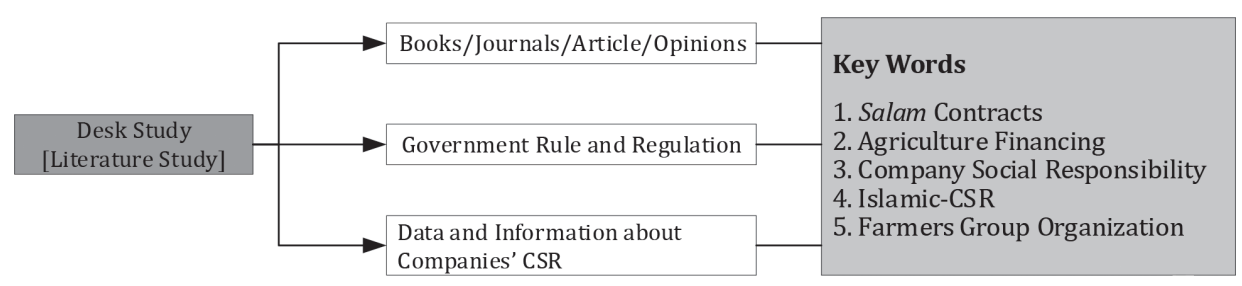

The next important stage in constructing this research about agriculture financing by using salam contract integrated with the Islamic-CSR concept is to proceed with FGD and in-depth interviews. Determining the key informants is more crucial due to the scientific degree of competence and the level of decision making. FGD and interviews are intended to facilitate the dialogue process on the theoretical framework coming from the outcome of the desk study. On this phase, the essential fact and information are derived in order to obtain and shape the secondary data analysis coming from desk study. The key informant on FGD and interviews are selected to represent stakeholders such as local government policymakers, financial service authority, and company disbursing CSR and Islamic bank and Islamic cooperative (BMT). Zakat institutions are also involved in the process of secondary data by discussing about their role in order to screen and monitor the recipients of the farmers salam contract recipients. The research will extend its critical and analytical part through the direct observation of farmers' activities, especially the farmer group organization as a prominent object in ensuring the work-ability of the salam contract.

Table 1. The Key Informants in FGD and Interviews

\begin{tabular}{|c|c|c|c|}
\hline No & Representation & Relevancy & Key Informants \\
\hline 1. & Local Government & $\begin{array}{l}\text { 1. Policy Makers } \\
\text { 2. Program Supervisors } \\
\text { 3. Responsibility and Duty }\end{array}$ & Tuban Trade Service \\
\hline 2. & $\begin{array}{l}\text { Companies Located at } \\
\text { Tuban }\end{array}$ & $\begin{array}{l}\text { 1. CSR Fund Owner } \\
\text { 2. Social Responsibility }\end{array}$ & $\begin{array}{l}\text { CSR Division of PT. } \\
\text { Semen Indonesia }\end{array}$ \\
\hline 3. & $\begin{array}{l}\text { Paddy Farmers in } \\
\text { Tuban Regency }\end{array}$ & 1. Object of Study & $\begin{array}{l}\text { Paddy Farmers in Tuban } \\
\text { Regency, surrounding } \\
\text { cement factory }\end{array}$ \\
\hline 4. & Islamic Bank & $\begin{array}{l}\text { 1. CSR Fund-Channeling } \\
\text { Institution }\end{array}$ & $\begin{array}{l}\text { Bank Syariah Mandiri and } \\
\text { Bank Muamalat }\end{array}$ \\
\hline
\end{tabular}




\begin{tabular}{|c|c|c|c|}
\hline 5. & $\begin{array}{l}\text { Farmers Group } \\
\text { Organization }+ \\
\text { BMT Cooperatives }\end{array}$ & $\begin{array}{l}\text { 1. The Main Players of Salam } \\
\text { Contract } \\
\text { 2. Salam Contract Guarantor } \\
\text { 3. Buyers and Managers }\end{array}$ & $\begin{array}{l}\text { Paddy Farmers Group at } \\
\text { Widang District Tuban } \\
\text { regency } \\
\text { BMT Mandiri Sejahtera }\end{array}$ \\
\hline 6. & Zakat Institution & $\begin{array}{l}\text { 1. Supporting intuition that } \\
\text { screens and supervises the } \\
\text { program }\end{array}$ & $\begin{array}{l}\text { LAZNAS Al Azhar } \\
\text { Indonesia }\end{array}$ \\
\hline 7. & $\begin{array}{l}\text { Indonesia Bureau of } \\
\text { Logistics }\end{array}$ & $\begin{array}{l}\text { 1. Paddy Warehouse and Trading } \\
\text { Unit } \\
\text { 2. The Ultimate Buyers of Paddy } \\
\text { Production }\end{array}$ & PT. BULOG Tuban \\
\hline 8. & $\begin{array}{l}\text { The Key Informants } \\
\text { such as Intellectuals, } \\
\text { Experts and Ulemas in } \\
\text { The Field of Study }\end{array}$ & \multicolumn{2}{|c|}{$\begin{array}{l}\text { Determined in the interviews } \\
\text { Sigit Iko Sugondo (Director of LAZNAS Al Azhar Indonesia) } \\
\text { Bambang Tutuko (Hedging Analysis Expert) }\end{array}$} \\
\hline
\end{tabular}

There are several reasons why researchers choose to explore the mechanisms of applying agricultural financing contracts concerning farmers in Tuban Regency:

1. Tuban Regency is one of the three Muslim populated cities with the neighboring territory: Gresik (Sunan Giri and Maulana Malik Ibrahim), Lamongan (Sunan Drajad), and Tuban (Sunan Bonang). Thus, the nuances of Islams can be said to be inherent in the activities of the local communities in the trade of agricultural commodities.

2. There is an active commodity warehouse running a Warehouse Receipt System (SRG) for grain and corn commodities (Bappebti, 2016). This SRG warehouse activity can be used as an indicator of the commodity trading activity in the area.

3. Grain Commodity is a commodity with the largest number of warehouse receipt transaction until the year 2016 was 2,124 receipts, $73,026,16$ ton, and total financing value IDR 224.813.412,230 (Bappebti, 2016).

4. Tuban Regency has become the location for facilitating the operations of various large companies such as PT. Cement, Indonesia and PT. Holcim Cement which has CSR potential funding due to its activities that changes environmental contours.

5. Various activities of farmers through the organization of farmer groups (GAPOKTAN) has been running in Tuban Regency.

6. Islamic financial institutions such as sharia banks and cooperatives and BMT have been in existence and operated in the Tuban Regency. 


\section{Discussion and Analysis}

\section{The Farmers' Difficulty to Access Islamic Banking Products}

The need to obtain cash during the planting period is very important for farmers. This is because farmers have various needs like the daily needs of their family and the additional cost of farming, during the planting period. When farmers are unable to obtain financing facilities to maintain cash flows before harvest, they tend to seek obtainable funds from other parties. The need for a quick loan is the weak point of bargaining power for the farmers. The situation would be more difficult if the lending party has the intentions to trap the farmers by purchasing the harvest at lower prices, in this case, the so-called loan-sharks who want to buy farmers' harvests at low prices. Farmers who are already tied to the loan from money lenders will find it difficult to hedge their crops. The sale of paddy grain at harvest time should go to the loan-sharks because such transaction for farmers is a payback of the debt, so it is a form of debt repayment using wet rice. Farmers who need quick money will find it difficult to refuse such an easy strategy.

Farmers' efforts to apply for a financing product from their official banking institutions including Islamic banks, cannot be accomplished due to the absence of tangible collateral such as land ownership certificate and motor vehicles in order to meet the banking requirements for the collection of loans. When such collateral is available, the farmers must then follow the banking preconditions with the murabahah or Mudarrabah contracts that enforce monthly fixed instalments and payments on instalment. In contrast, farmers' income from producing new paddy grain can be monetized after a harvest time of 4 months. Moreover, farmers should accept paddy grain prices that tend to decrease when the harvest period comes, and relatively agricultural costs remain fixed and even can rise. Farming jobs focusing on the process of production and sales directly will tend to lose and not become profitable. Islamic banks are not interested in opening agricultural financing because they consider agricultural business as a non-profit business at small scale level.

\section{The Implementation Challenge of Islamic Bank Financing in Agriculture Sector through Salam Contract}

Salam contract financing still faces several issues related to risk and risk management. The salam contract risk to be paid by any financial institution is usually in the form of the farmers' default due to the crop failure. The only guarantee of having the financial institutions to secure and pay bank financing is dependent on the delivery of the harvest when it matures. In cases of problems of harvesting or 
crop failure, the financial institution would experience a default risk. The solution to channelling the salam contract financing scheme to the farmers offered by financial institutions relies on a judicious process of finding ways to justify the risks of crop failure. Changes in the outlook of both banks and non-banks financial institutions are urgently needed to reduce the risk of financing this salam contract so that it can be used by farmers who can eventually use it to increase their bargaining power in hedging and to postpone selling action when harvest prices fall.

\section{The Challenges of Distinctive Business Cycle between Farming and Banking}

Under certain idyllic conditions, the combined capital called the gapoktan, gained from the members of the farmer groups (farmer group organization, called gapoktan) that have the joint business groups is contributed from the member farmers. However, under special situations, the condition of most of the farmers who are mostly still mustahik (groups receiving zakat, considered the poor), are given by the gapoktan in order to get support as another source of income for capital. Gapoktan requires a capital source whose financing scheme is in agreement with the agricultural scheme. Islamic banks are usually the first alternative considered as a source of capital for the Gapoktan. However, the incompatibility of the Islamic bank financing schemes following the required bankable" and monthly payment contradicts the agricultural cash flow scheme (cash inflows 3-4 months) which could cause problems for farmer groups and farmers.

Graph 2: The Distinctive Business Cycle between Banking and Agriculture

\section{Farming Cycle}

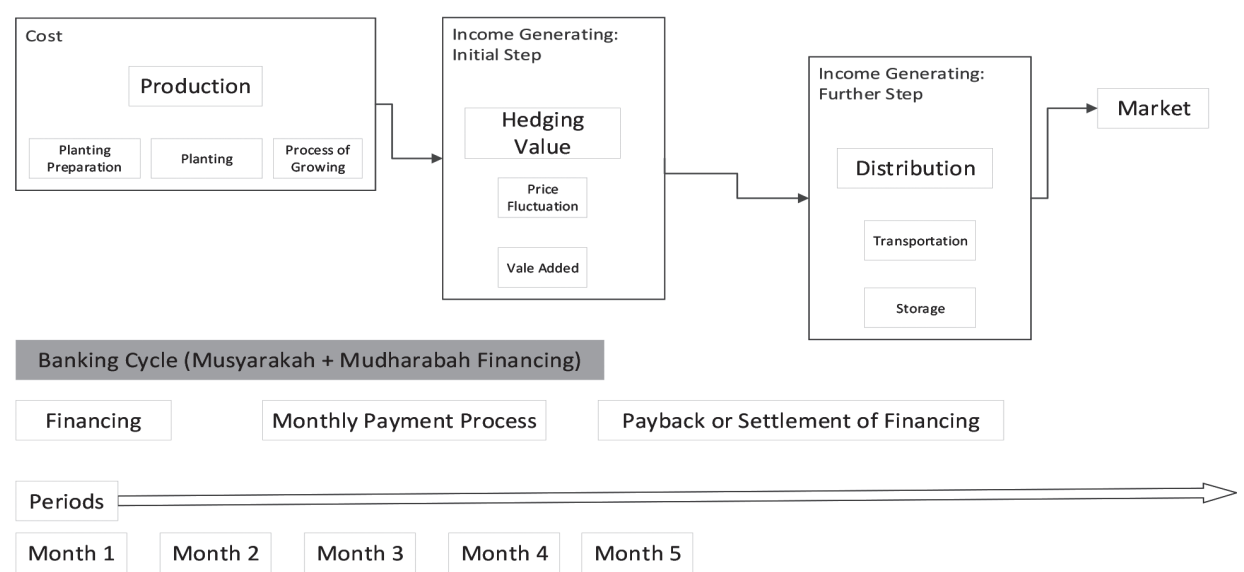


The capital and financing problem for farmers shows that there is no agreement between the agricultural business payment scheme and the Islamic bank financing scheme. It is good in terms of the potential products been offered to the public. The expansion of agricultural products creates room for opportunities for an alternative source of capital sources to support farmers. From the discussion, the result shows incompatibility between the farmers (gapoktan) and Islamic banks due to regulations of the commercial banking which are usually very rigid and organized under the Banking Act. The solution, therefore, lies in the existence of an alternative source of capital sources that are not bound by banking regulations. These source of financing which is not attached to the central bank regulations is the third party fund coming from the society through proper campaigning for the zakat, infäq, sadaqah (ZIS), cash waqf (cash waqf), as well as all other sources of financing such as CSR productively.

\section{Islamic CSR Model as an Answer for Agriculture Financing Scheme}

The key to the proper implementation of the salam contract in order to improve the welfare of farmers in Tuban Regency is making available cheap and flexible funds to the farmers. The funds must be well managed and channelled professionally and productively through the existing Islamic economic institutions. CSR funding is considered one of the most acceptable alternatives needed for businesses operating in Tuban regency. The allocation of most of the CSR funds from the companies is necessary and expected to be a new source of financial support for the farmers. These funds are most likely to be applied as part of agricultural financing, which has the highest degree of flexibility. They also become a potential productive cash waqf contributed by the company. Compared to the cash waqf, it is expected to increase in value as the productive CSR funds can be managed at the same amount of time. Companies issuing CSR fund is expected to release corporate zakat or zakat income for their employees. These CSR funds are different from the zakat fund in the Islamic economics terminology. 
Table 2. The Comparison between the CSR Fund, Waqf, and ZIS

\begin{tabular}{llll}
\hline Aspects & CSR & Waqf & ZIS (Zakat, Infãq, and Shodaqoh) \\
\hline $\begin{array}{l}\text { Fund Owner } \\
\text { Potency }\end{array}$ & Company & Society & Muzzaki (Zakat Payers) \\
Beneficiary & Society (The Poor) & Society & Mustahiq (8 Zakat Recipients) \\
Precondition & $\begin{array}{l}\text { Government } \\
\text { Regulation }\end{array}$ & $\begin{array}{l}\text { Syariah } \\
\text { Guidance }\end{array}$ & Syariah Guiance \\
Perpetuity of Fund & $\begin{array}{l}\text { Not an obligation, } \\
\text { but a benefit to } \\
\text { society }\end{array}$ & $\begin{array}{l}\text { An } \\
\text { obligation }\end{array}$ & Fully Allocated, Ineligible \\
\hline
\end{tabular}

Graph 3: The Islamic CSR Model

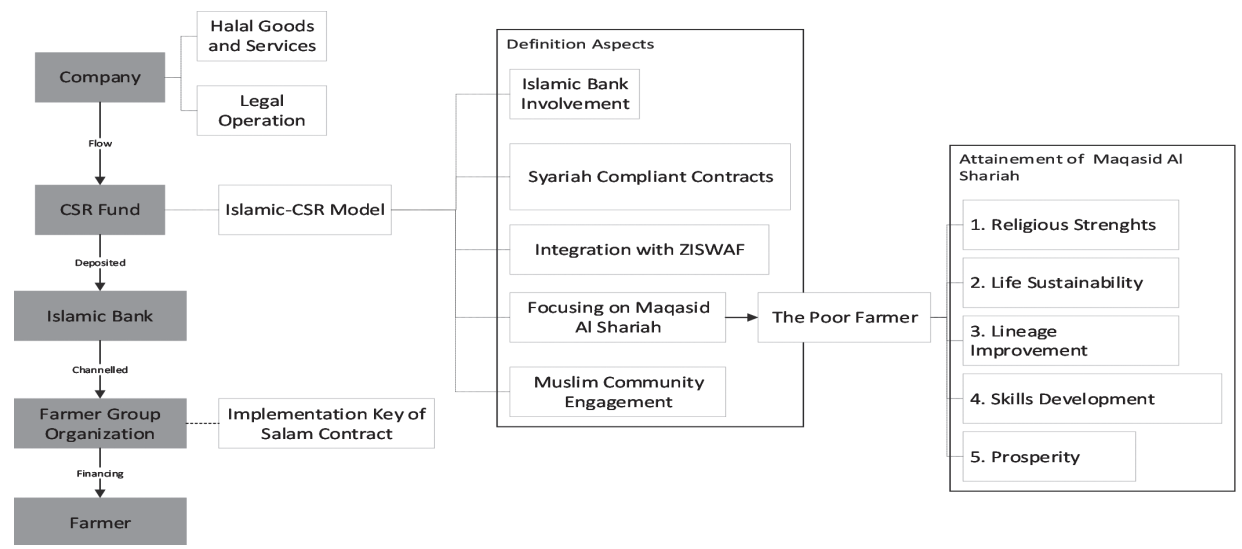

\section{The Conceptual Scheme of Islamic-CSR Integration and Agriculture Financing with Salam Contract}

The financial application of the salam contract for farmers in Tuban Regency works gradually with two pillars; the first is a third party supporting fund while the second is a professional management institution. The Islamic-administered CSR would become an immediate source of funding and implementation process for a salam contract. While the organization of the farmer groups (gapoktan) is a legal entity of Islamic cooperative, in reality, the business unit of the paddy mill and the trading aspect is the key to run the salam contract. The participation of the Islamic banks in the party who absorbs CSR funds is used as a third party fund with a financing scheme to the agricultural industry. The farmer group organization is the body responsible for the management of the bank's financing channel, which would 
be used in the agricultural financial products. Not only can the gapoktan become fund managers, but it must possess the ability to process and sell products harvested from farmers in order to return funds obtained from the Islamic banks.

All necessary bodies involved in the process of integrating the process of the Islamic-CSR and salam contract for the farmers will collect incentives. Companies contributing towards the CSR funds through the Islamic banks would most definitely have their CSR funds managed productively, and in return, generated funds from the Islamic banks can be used for various social programs. Instead of direct program which engages farmers, allocating CSR fund through the Islamic banking channel is preferred because of their knowledge and professionalism in the management of fund institutions. Islamic banks will have a share of Mudārabah financing for Gapoktan. For such CSR funds, the treatment has enabled the flexibility of a structured financing scheme as the fund is not a subject of a high margin or profit-sharing rate with rapid return period. For gapoktan, the CSR funds mostly provided by the Islamic banks are linked to the farmers applying the financing with a salam contract. Gapoktan receives two benefits; profit-sharing from managing a productive salam financing and income from milling the grain paddy harvest into the white rice and even vending directly to the end consumer.

Graph 4: Operationalization of the Concept of Islamic CSR Model and Agriculture Financing

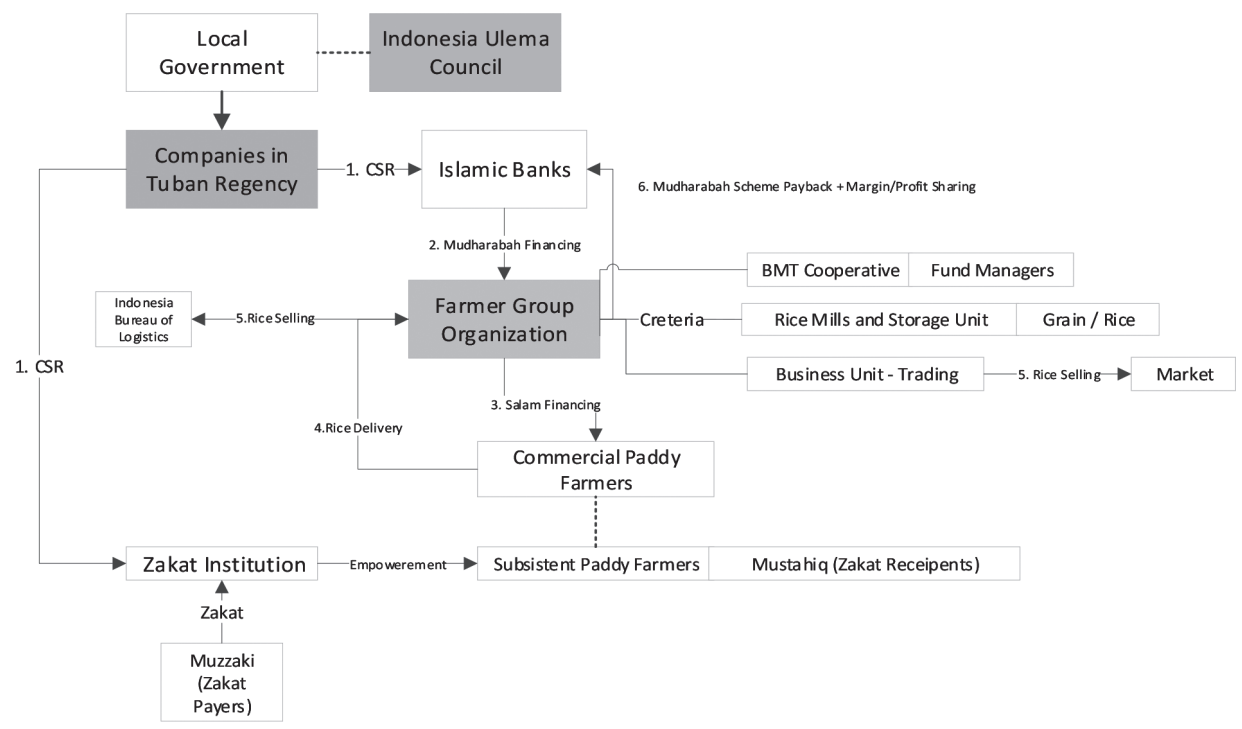




\section{Operationalization of Islamic Cooperatives (BMT) and Farmer Group Organizations to be Joint Ventures or Business Groups}

As a non-bank financial institution, Bait al-Māl wa Tamwil (BMT) has a very crucial role to play in providing Islamic financing, in order to act as a support system on the cash flow of the farmers, before the harvest time. Financing facility for the farmers before the harvest time will be able to cut off the dependence of the farmers on the so-called middlemen or loan sharks. When the farmers become nondependent on debt to the middlemen, they can safely secure their harvested crops and paddy by delaying the sales at a lower price. This condition enables the farmers to patiently wait so they can sell their crops at better prices. In the operation of the salam contract and a precondition, the farmers trade their crop to joint venture group. BMT as a non-bank financial institution that is not bound by banking regulations, which requires the assurance of assets and conditions of bankable farmers, is expected to be very flexible in order to properly channel financing for farmers.

Salam contract financing from BMT (part of KUB, Joint Venture or Business Group) to farmers is the best solution to break the attachment of farmers to mediators. With salam contract, farmers can get two benefits in two ways; obtaining the cash before the harvest time so they can finance their personal needs and obtaining the certainty of selling at an agreed contract price contract. Risk mitigation of crop failure is one problem which could be encountered and can lead to a default in risk for gapoktan and BMT.

From these in-depth interviews, it shows that by establishing these Islamic cooperatives which consists of farmers and the farmer groups, KUB can have an independent fund from non-binding members or external parties and this condition can become more flexible so as to support salam financing, where its pattern uses cash flow cycle for agriculture based on the harvest season and not monthly as the bank rules. In addition to achieving financing harmony on the needs of farmers, the distribution of salam financing through KUB is to be the best solution due to the obligation from Gapoktan (KUB) to buy crops as at the time of maturity, which cannot possibly be done through the Islamic banks due to its regulation boundaries on banking business nature.

KUB and BMT established by farmer groups would become a means of risk mitigation for the salam financing distribution. Since the capital of BMT comes from the farmers, it has been channelled back to the needs of the members of the group and the sustainability of the BMT activities will become a joint responsibility. The results of these interviews show that the feasibility study on member farmers 
taking salam contract financing will be shared by other farmer members; in other words, it will become a collective appraisal process. With an assurance from the head of the farmer group, the BMT Board will be able to obtain accurate data from each of its member from their production and the financial track record and farmers' production interested in applying for financing.

\section{Graph 5: The Model of Joint Venture Group}

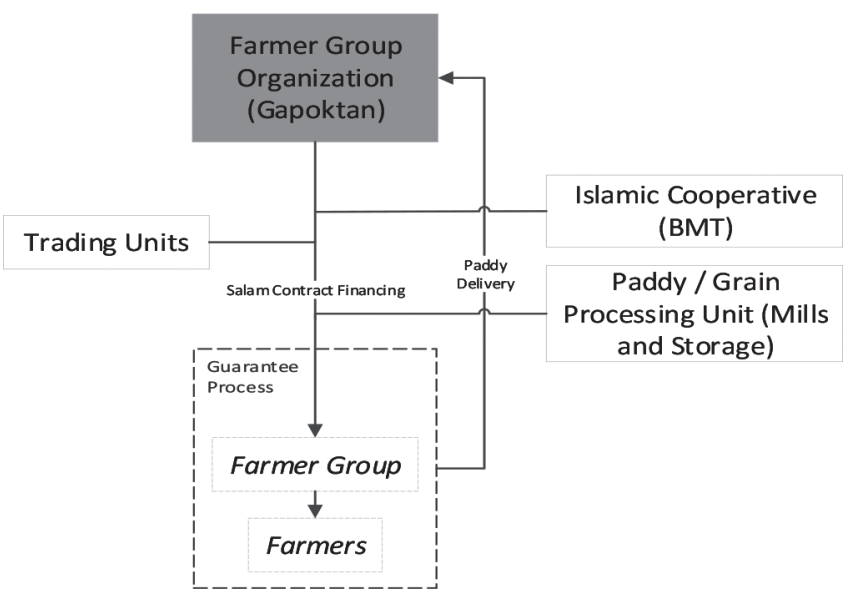

The farmer, who proposes the financing, will feel a great deal of responsibility to complete the salam contract well in accordance with the stated agreement in order to protect his good name and also protect his family from the preying eyes of other farmers in the community/group. On the other hand, if farmers who apply for salam financing experiences crop failures, it becomes the responsibility of the other members to help the farmer return the loan to KUB and BMT (collective guarantee).

Collective appraisal and collective guarantee must be a condition for the approval of salam financing contract from BMT. If both of these requirements are not met, the farmer is considered not to be qualified to meet the requirements necessary to receive the financing. This collective responsibility is a way of mitigating the salam contract risk borne by BMT, which is established by farmers group organization. As initial information on farmers' production and financial records, the head of the farmer group indirectly acts as a personal guarantor to ensure that the group is ready to bear the risks arising from the salam contract. Thus, the BMT established by the farmer group becomes an instrument for farmers to unify their goals and protect their common welfare. 
In the absence of a warehouse, KUB can cooperate with the musharakah based-Warehouse Manager (Indonesia Bureau of Logistics, BULOG) on a profitsharing system, where the manager gets a portion of the profit as benefits for storing of the grain paddy, and selling after its prices increasing. The grain paddy from KUB as an example goes into the warehouse (BULOG) of 100 tons $(100,000 \mathrm{~kg})$ at a price of IDR 4.500, - per kg, it is then stored and sold 40 days later at the price of IDR 5.500, -, the warehouse manager will benefit a share of the percentage of the agreed net profit on sale, as calculated below:

Net Profit Sale $=(($ IDR $5.500-$ IDR 4.500 $) \times 100,000 \mathrm{~kg})-$ operating costs delay (transportation costs, storage costs, warehouse administration costs).

Revenue Sharing for Warehouse Manager $=$ X\% x Net Profit Selling after Postponement.

\section{Graph 6: Operationalization of the Joint Group Organization (KUB)}

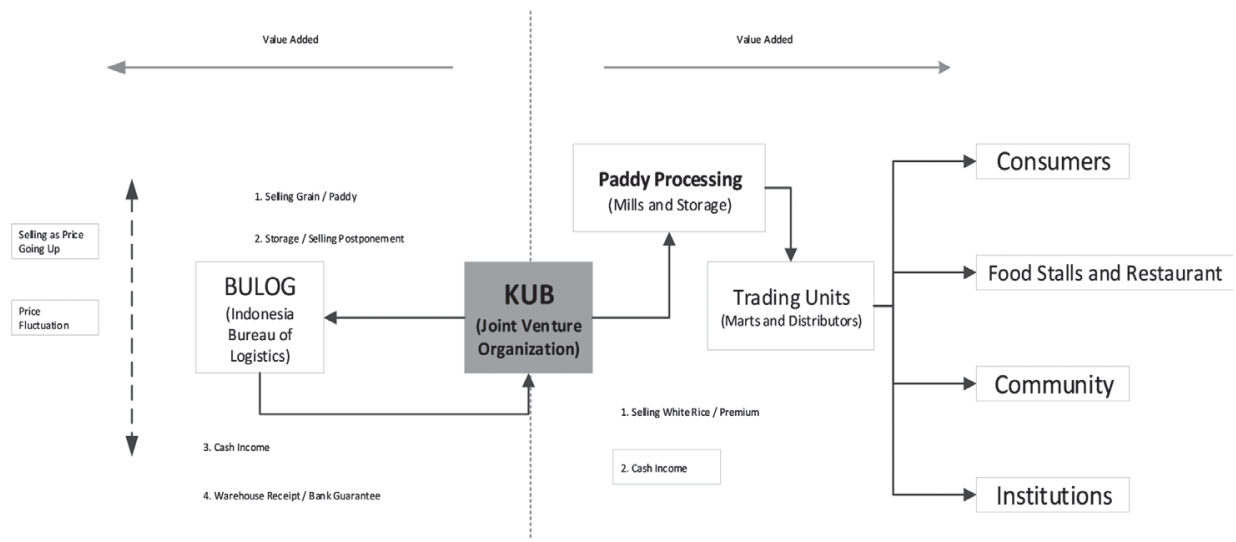

Why use a profit-sharing system? With the revenue-sharing system, the warehouse manager is able to receive a better profit-sharing portion rather than by charging daily or weekly fees. In addition, KUB can also benefit from cash flow where the operational costs of postponement of sale are not fully charged but are shared with the warehouse manager as the cost of the musharakah cooperation between both parties.

In addition to selling more crops in the form of dried grain or paddy, KUB can make other alternatives that are also profitable, like self-processing of dried grain or paddy into ready-to-sell rice to end consumers/users. By selling directly to consumers, they can benefit from the added-value, wherein real fact, this practice 
is been done by middlemen who buy the grain and paddy at a lower price from farmers and sell it in the form of white rice, especially when there is an increase in price increases. To enable them to sell in the form of rice, KUB could set up a Rice Processing Unit which would have a rice milling machine and a storage warehouse. They can also cooperate with other Rice Processing Units with musharaka-based on agreement. The profit-sharing between KUB and Rice Processing Unit is calculated based on agreement in the form of a certain percentage of the added value generated. Here is the profit-sharing calculation for the Rice Processing Unit based on Added Value from grain to rice:

Added Value (Grain to Rice): ((rice selling price-grain price entered machine) $\mathrm{x}$ total $\mathrm{kg}$ of rice sold) - operating costs (processing, packaging, until rice sold).

Revenue Share for Rice Processing Unit: X\% x Added Value (Grain to Rice).

The advantage of KUB by selling the crops in the form of rice is certainly higher than selling the crop in the form of grain or paddy due to the emergence of added significant value-added. Thus, the principle can conclude that the business to provide value-added in commodities is also a means of hedging. Bait al-Mãl wa Tamwil (BMT) established by the farmer group organization is to become a solution so that farmers can hedge against fluctuations in grain prices, especially during the harvest.

Salam financing designed by the BMTs to the farmers allows them to release their financial attachment to the middleman or loan sharks, thus having to give them the option to postpone the sale during the harvest. Additionally, farmers can shorten the supply chain between themselves and the final consumer through BMT and, therefore, they can enjoy the benefits of the sale of end products like the white rice, which is only enjoyed by middlemen. The scheme is possible via KUB (joint venture group) which manages the paddy farming business cycle from its backward and forward linkage. This mechanism still leaves one important problem, which is about how BMT would ensure the sale of the final product. Without a clear target market, BMTs that are part of KUB are still uncertain about getting cash as a payback mechanism, starting from Islamic financing to farmers, buying their crops and selling them into the market. 


\section{The Paddy Hedging: Selling Postponement and Improving Value Added}

Non-banking nature of the Islamic financing for farmers is a critical solution to farmers' problems. The salam contract is the most appropriate type of Islamic financing for farmers. Such financing is done with the aid of a flexible contract, where KUB acts as the buyer of the farmer's products. Salam attachment is in a buying and selling contract whereby the buyer makes payment in full before getting the product while the seller, in this case, the farmer, will deliver the goods in the future as agreed by both parties. KUB and farmers will agree ahead of time on the price, quality, quantity, and delivery time of commodities (crops) in the future. Price agreements play an important role in salam financing, as it a determining factor on the number of funds provided by the financial institutions to farmers. The agreed price must be beneficial to both parties, having KUB as buyers and the farmers as sellers. If the prices are determined based on a lower estimation especially during the harvest period, then the farmers will suffer heavy loses, because there will be no much difference between the finance made available to the farmers by the middlemen and the financial institutions. Financial institutions should, therefore, be more "aligned" with the farmers by reaching an agreement on mutually beneficial prices.

With the salam financing, farmers can get some benefits such as:

1. Obtaining cash before harvest, with the guarantee of delivering the crops.

2. The certainty of the sale of crops because salam is a contract of sale and purchase; bay al-salam, where the buyer gives advanced payment in full to the farmers, and later the farmer will deliver the crop to the buyer.

\section{The Intervention of Zakat Institution and its Instruments}

From the in-depth interview results, it can be interpreted that the Islamic social fund (zakat, infäq, sadaqah, and waqf) managed by the Zakat Institutions plays a role as a "kaffah" solution (from upstream to downstream), ranging from empowering farmers, production, capital BMT farmer, storage, rice processing, to sales. The involvement of Zakat Institutions integrated with CSR, for example, the PT. Cement Indonesia (Persero) Tbk. will provide opportunities to manage corporate social funds and religious, social funds to be more integrative and productive.

The support of ZIS and Waqf Institutions for the welfare of the farmers is by channelling ZIS (zakat, infäq, sadaqah and waqf) to support the capital of farmer groups and KUB. In addition, the cooperation between farmer groups, ZIS and 
Wakaf Institutions can act as a solution to several difficulties in collecting ZIS and Waqf. In fact, the main focus of the zakat institutions is to find muzakki (ZIS donors). The encouragement of ZISWAF (zakat, infäq, halaqah, and waqf) programs by the ZISWAF and BMT Institutions for the welfare of Indonesian farmers, within the framework of KUB, will provide clarity to the muzakki on who will become the mustahik on the right profile. By learning more closely its mustahik, the muzakki would certainly be more motivated to pay ZISWAF. Through this program, zakat funds are distributed by the ZIS Institutions to farmers, who are classified asnaf (zakat recipient / the poor) so much that they can fulfil their daily needs. At a later stage, the poor and needy farmers are ready to be empowered in commercial agriculture.

\section{Conclusion And Limitation of the Study}

\section{Conclusion}

The ability of farmers to raise funds towards their planting period or before their harvest period is determined by the process involved in the production. This is mostly because farmers have different needs during the production period, such as family needs and the cost of planting during the production period. They seek to obtain financing from informal sources rather than official banking institutions, including sharia banks. However, this is mostly due to the lack of collateral, such as land and motor vehicles necessary to meet banking requirements. Even when physical security is available, farmers must still follow the banking conditions of murabahah or Mudarabah engagement with monthly fixed instalments.

Salam financing designed especially for agriculture, has still faced lots of problems in its implementation, especially in relation to risk management for financial institutions. The biggest risk exposed by the financial institutions is in the failure to harvest. These financial institutions avoid contracts of agricultural financing with salam contract. To develop agriculture financing products, the combined capital of the farmer groups (gapoktan) is key solution to the problem. The condition of farmers who are still mostly mustahik have as consequences; they need support from other sources of capital. The capital problem for farmers indicates that there is a conflict in the agricultural business payment scheme and the Islamic bank financing scheme, which on the one hand, is an important opportunity for them. The effectiveness is by opening an opportunity for alternative capital sources to help support farmers. CSR funds 
provided to Islamic banks can eventually become an alternative productive cash waqf or could remain corporate CSR funds in the implementation process of the salam.

The key to the implementation of the salam contract in regards to improving the welfare of farmers in Tuban Regency is through the availability of cost-effective and flexible funds which must be managed professionally and productively through the sharia economic institutions that are actively functional. The financing application with the salam contract for farmers in Tuban Regency deals with two pillars; a supportive third party fund that supports the farmers and the second is a professional management institution. The Islamic-administered CSR will be the fastest source of fund that supports the realization of the salam contract. Furthermore, the organization of farmer groups as a legal entity of Islamic cooperative with the business unit of rice processing and trading is the key to the field of salam contract operationalization.

\section{Limitation of the Study}

Research on the implementation of salam contract for agricultural financing is very important in developing an Islamic agribusiness value chain. Beneficiaries and parties involved include companies, Islamic banking institutions, farmer group organizations, traders and Islamic cooperative communities (BMTs). The research involving the agricultural finance system has evolved from intangible roots and evaluation analysis towards application. Where the conceptual implementation of the salam contract that is combined with the management of CSR, more detailed and measurable experimental research is needed so funds can be examined with the involvement of real funds as the pilot project and when a conceptual experiment is conducted in a given period of time involving limited funds within a period of 1 year which is a 2-3 times the planting season, possible obstacles can be identified. Hence, research on the implementation research of the salam contract for farmers will become more accurate and well structured.

\section{Acknowledgement}

Special thanks from the Author to the Ministry of Research, Technology and Higher Education of the Republic of Indonesia for the 2017 research grant which contributed to making the study possible. 


\section{References}

Adi, Fajar. 2013. Analysis of Sharia Financing for Agricultural Sector Using Akad Bai 'Salam (Case Study on Farmers In Bogor Regency). Thesis Department of Management Faculty of Economics UI: Not Published.

Akhtar, Mohd Javed 2007. Corporate Social Responsibility in Islam. PhD Thesis Submitted in Auckland University of Technology: New Zeland, Unpublished.

Al Zaabi, Obaid Saif. 2010. "Salam Contract in Islamic Law: A Survey, Review of Islamic Economics." International Association for Islamic Economics 14(2): 91-122.

Ayub, Muhammad. 2007. Understanding Islamic Finance. England: John Wiley \& Sons, Ltd.

Bank Indonesia. 2015. Penelitian Skema Pembiayaan Pertanian dengan Konsep Pendekatan Rantai Nilai (Value Chain). Retrieved from https:/www.bi.go.id Bank Indonesia. 2015. Research of Agricultural Financing Scheme with Value Chain Approach. Retrieved from https://www.bi.go.id

BAPPEBTI. 2016. Badan Pengawas Perdagangan Berjangka Komoditi/ Commodity Futures Trading Supervisory Agency. Retrieved from https://www.bappebti. go.id/.

Crane, Andrew \& Dirk Matten. 2007. Corporate Social Responsibility: Theories and Concepts of CSR. Los Angeles USA: SAGE Publications.

Darus, Faizah, Haslinda Yusoff, Dayang Milianna Abang Naim \& Mustaffa Mohamed Zain. 2013. "Islamic Corporate Social Responsibility (i-CSR) Framework from the Perspective of Maqasid al-Syariah and Maslahah." Issues in Social and Environmental Accounting 7(2): 102-112.

Ehsan Asim, Muhammad Asghar Shahzad. 2015. "Bay Salam: A Proposed Model for Shari'ah Compliant Agriculture Financing." Business \& Economic Review 7(1): 67-80.

Elgari, Muhammad 'Ali. 2010. Hedging mechanism in Islamic financial operations. Paper presented to the $7^{\text {th }}$ conference of Shariah Boards of the Islamic Financial Institutions-Auditing Unit for the Islamic Financial Institutions. Jeddah: King Abdul Aziz University.

Financial Service Authority. 2017. Islamic Banking Statistics, 2017. Retrieved from https://www.ojk.go.id

Fombrun, C. J., 1997. Three Pillars of Corporate Citizenship in Corporate Global 
Citizenship, ed. Noel M. Tichy, Andrew R. McGill, and Lynda St. Clair. San Francisco: New Lexington Press.

Government of the Republic of Indonesia. 2007. UU No 40 Tahun 2007 Tentang Perseroan Terbatas. Retrieved from https://www.ojk.go.id/sustainablefinance/id/peraturan/undang-undang/Pages/Undang-Undang-No.-40tahun-2007-tentang-Perseroan-Terbatas.aspx.

Government of Tuban Regency, 2017. Data Statistical of Tuban. Retrieved from http://tubankab.go.id/berita/detilberita/846

Kaleem, Ahmad \& Rana Wajid. 2009. Application of Islamic banking instrument (Bai Salam) for Agriculture Financing in Pakistan. British Food Journal 111(3): 275-292. Retrieved from DOI 10.1108/00070700910941471.

Khursis, Muhammad Adnan, Abdulrahman Al-Ali, Ahmed Ali Soliman \& Salmiah Mohd Amin. 2014. "Developing an Islamic Corporate Social Responsibility Model (ICSR)". Competitiveness Review Journal International Business 24(4): 258-274.

Machlup, Fritz. 1978. Methodology of economics and other social sciences. New York: Academic Press, Inc.

Miles, Matthew B, A Michael Huberman \& Johnny Saldana. 2014. Qualitative Data Analysis A Methods Sourcebooks: Third Edition. USA: SAGE Publication: Arizona State University.

National Ulema Council of Indonesia. 2000. National Shari' ah Council Fatwa No: 04 / DSN-MUI / IV / 2000 About Murabahah.

National Ulema Council of Indonesia. 2000. National Shari' ah Council Fatwa No: 05 / DSN-MUI / IV / 2000 about Salam Sale and Purchase

National Ulema Council of Indonesia 2000. National Shari'ah Council Fatwa No: 07 / DSN-MUI / IV / 2000 about Mudārabah Financing (Qiradh)

Qusthoniah. 2016. "Critical Analysis of Salam Covenant in Syariah Banking." Journal of Shariah V(1). Retrieved from http://ejournal.fiaiunisi.ac.id.

Roziq, Ahmad, Sebastian Viphindrarin \& Sampeadi. 2014. "Financing Model Greetings on Cassava Farmers And Small Businesses Cassava In Jember District" Journal of Accounting Jember University 12(2).

Taman, Salma. 2011. "The Concept of Corporate Social Responsibility in Islamic Law”. Ind. Int'l \& Comp. L. Review 21(3): 481-508.

Thorne, Debbie M, O.C Ferrell \& Linda Ferrell. 2008. Business and Society: A Strategic Approach to Social Responsibility, Houghton Mifflin Company. USA: Boston. 
Yin, Robert. K. 2009. Case Study Research Design and Method: Fourth Edition, Applied Social Research Method Series Volume 5. California USA: SAGE Publishing. 